\title{
Molecular targets for radiation oncology in prostate cancer
}

\author{
1 Department of Radiation Oncology, University of Massachusetts Medical School, Worcester, MA, USA \\ 2 Department of Cancer Biology, Thomas Jefferson University, Philadelphia, PA, USA \\ ${ }^{3}$ Department of Cell Biology, University of Massachusetts Medical School, Worcester, MA, USA \\ ${ }_{4}$ Department of Surgery, University of Massachusetts Medical School, Worcester, MA, USA
}

Tao Wang ${ }^{1}$, Lucia R. Languino², Jane Lian ${ }^{3}$, Gary Stein ${ }^{3}$, Michael Blute $^{4}$ and Thomas J. FitzGerald ${ }^{\text {* }}$

\section{Edited by:}

Joe O'Sullivan, Queen's University Belfast, UK

\section{Reviewed by:}

Michael L. Freeman, Vanderbilt University School of Medicine, USA Anatoly Dritschilo, Georgetown University School of Medicine, USA

\section{${ }^{*}$ Correspondence:}

Thomas J. FitzGerald, Department of Radiation Oncology, University of Massachusetts Medical School, 55 Lake Avenue North, Worcester, MA 01605, USA.

e-mail: tj.fitzgerald@umassmemorial.org
Recent selected developments of the molecular science of prostate cancer (PrCa) biology and radiation oncology are reviewed. We present potential targets for molecular integration treatment strategies with radiation therapy (RT), and highlight potential strategies for molecular treatment in combination with $\mathrm{RT}$ for patient care. We provide a synopsis of the information to date regarding molecular biology of $\mathrm{PrCa}$, and potential integrated research strategy for improved treatment of PrCa. Many patients with early-stage disease at presentation can be treated effectively with androgen ablation treatment, surgery, or RT. However, a significant portion of men are diagnosed with advanced stage/high-risk disease and these patients progress despite curative therapeutic intervention. Unfortunately, management options for these patients are limited and are not always successful including treatment for hormone refractory disease. In this review, we focus on molecules of extracellular matrix component, apoptosis, androgen receptor, RUNX, and DNA methylation. Expanding our knowledge of the molecular biology of PrCa will permit the development of novel treatment strategies integrated with RT to improve patient outcome

\section{Keywords: PrCa, radiation, AR, ECM/integrin, Runx2, DNA methylation, apoptosis}

\section{INTRODUCTION}

Prostate cancer ( $\mathrm{PrCa}$ ) is the most common non-cutaneous malignant disease and the second leading cause of cancer-related deaths among men in the United States (Jemal et al., 2010). Incidence varies considerably between countries and appears to be increasing as a result of more frequent and improved diagnostic tests, an aging population, and likely increase in the occurrence of the disease (Jemal et al., 2011). At presentation, $\mathrm{PrCa}$ is highly responsive to anti-androgen treatment (Isaacs, 1999; Heinlein and Chang, 2004). However, patients with long-term application of treatment can evolve to the disease resistant to androgen ablation (Wu et al., 2007). This is more commonly referred to as hormone refractory (HR) disease or castration resistant disease (Dehm and Tindall, 2006).

In addition to hormone ablation therapy (HBT), radiation therapy (RT) is an important primary treatment modality for localized PrCa, and recent advances in volumetric based intensity modulated radiation therapy (IMRT) and image guided radiation therapy (IGRT) have permitted RT dose escalation beyond 75 Gy with external therapy. This has reduced both biochemical failure rate and the development of metastasis (Pollack et al., 2002; Parker and Dearnaley, 2003; Pisansky, 2006). Despite these advances, patients with both intermediate and high-risk features can still relapse after definitive hormone treatment and/or RT (Catton et al., 2003). One possible reason for these failures from RT may be due to the intrinsic radioresistance of a subpopulation of prostate tumor clonogen within the tumor. PC contains a variety of heterogeneous cell subpopulations characterized by over expression of oncogenic proteins such as epidermal growth factor receptor (EGFR), sonic hedgehog, Wnt/B-catenin, c-Myc, Akt, and nuclear factor-kappaB (NF-KB) or inactivation of distinct tumor suppressor proteins such as phosphatase tensin homolog deleted on chromosome 10 (PTEN), Nkx3.1, p27KIP1, p53, and retinoblastoma (pRb). These molecules may cooperate for malignant transformation, tumor development, metastasis, and HBT resistance (Mimeault and Batra, 2006). Thus, elucidating the mechanisms of malignant progression from androgen dependence to independence and finding a molecular target for treatment of PrCa by increasing the efficacy of RT is an important strategy for improved management of PrCa (Bromfield et al., 2003).

In this review, we discuss the challenges that present to RT for PrCa. Several molecular mechanisms that may be important for the survival of PrCa cells are evaluated. We will focus on the biology of androgen receptor (AR), DNA methylation, and microenvironment and will evaluate their potential effect on radioresistance of PrCa. We hope to shed light in molecular targeting in combination of RT to improve outcome for treatment of patients with the disease.

\section{CHALLENGE TO RT}

The optimal management of PrCa relies on appropriate risk categorization. This is defined by pre-treatment prostate-specific antigen (PSA), clinical staging, imaging, when needed, and Gleason score on pathology review (Oesterling et al., 1995; Gleason and T.V.U.R. Group, 1997; Pisansky et al., 1997; Edge et al., 2010). In the future, somatic mutations may be used for classification (Kan et al., 2010). The use of RT in low-risk (T1-T2a, PSA $10 \mathrm{ng} / \mathrm{ml}$ and Gleason score 6) and intermediate-risk (T1/T2, PSA $20 \mathrm{ng} / \mathrm{ml}$ and Gleason score 7) disease is well established, with comparable results to surgery in the era of modern RT. In addition, cancer-related outcomes in many intermediate and advanced patients with RT are improved with the use of adjuvant hormonal therapy (Pollack et al., 1995). Benefits to sub-categories of patients with intermediate-risk factors need to 
be elucidated in the era of dose-escalated RT. Because of low $\alpha / \beta$ ratio, hypofractionated RT and brachytherapy using biologically equivalent doses also has the potential to improve the therapeutic index and to reduce overall treatment time (Brenner and Hall, 1999; Fowler et al., 2003). The sensitivity differential between tumor and normal tissues may favor the use of hypofractionated radiotherapy schedules for all patients with different stages of diseases. HBT improved the freedom from biochemical failure outcome index, but did not affect the low $\alpha / \beta$ value (Miralbell et al., 2011). In patients with high-risk disease (T3-T4, PSA > $20 \mathrm{ng} / \mathrm{ml}$ or Gleason score 7-10), radiation with HBT has become a standard treatment (Coblentz et al., 2002; Sandler, 2004). The challenges are to determine the optimal duration of HBT, assess the use of regional dose escalation, and to determine the benefit of chemotherapy and targeted therapies that can be used with RT.

For regionally advanced $\mathrm{PrCa}, \mathrm{RT}$ is a primary treatment option. RT is also an adjuvant treatment for prostatectomy (Szostak and Kyprianou, 2000). Successful treatment of PrCa patients by RT often depends on tumor radiosensitivity and the radiation tolerance of normal tissues. Systemic therapies that are cytotoxic and/or radiosensitizing are often combined with RT to improve therapeutic outcomes (Garzotto et al., 1999; Lin et al., 2003; Belka et al., 2004). This facilitates the use of RT with higher efficacy. Although the precise molecular mechanism by which radiation triggers cell death is not fully understood, the cytoplasmic membrane, DNA, and molecules associated with cell survival and cell death are major cellular targets (Higuchi, 2003; FitzGerald et al., 2004; Mishra, 2004). In spite of the development of modern RT technology including IMRT and IGRT, recurrence after RT can still occur albeit less common. A recent report claims that high percentage of patients treated for localized PrCa are at risk of recurrence, with half the recurrences occurring more than 10 years after treatment (Allen et al., 2007).

\section{ANDROGEN RECEPTOR AND ITS LIGAND: RATIONALES OF HORMONE THERAPY AND RT}

Androgen receptor belongs to the nuclear receptor gene superfamily and mediates transcription of various genes important for disease maintenance (Feldman and Feldman, 2001). Early-stage PrCa at diagnosis is usually responsive to anti-androgen treatment. More advanced phases of the disease may become resistant to therapy with subsequent recurrence (Isaacs, 1999; Heinlein and Chang, 2004). Synergism with HDT and RT has been shown in several clinical trials (Table 1). Patients receiving HBT and RT have an improved clinical outcome validated by several prognostic factors including PSA, local control, development of distant metastasis, and overall survival compared to patients receiving RT as monotherapy (Pollack et al., 1995; Bolla et al., 2002; Pilepich et al., 2005). For high-risk patients, clinical trials show that a combination of HBT (neoadjuvant and adjuvant) and curative RT has a better local control and disease-free survival for PrCa patients than RT alone (Pollack et al., 1999; Roach, 1999). Although the addition of HBT did not significantly improve freedom from biochemical failure survival or disease-free survival in all prostate cancer patients receiving dose-escalated RT, it did approach significance in highrisk patient subgroup (Valicenti et al., 2011).

For high-risk, locally advanced prostate adenocarcinoma, the combination of RT with 2-3 year HBT by LH-RH agonists is currently the recommended treatment. In patients with intermediaterisk of Gleason score 7 prostate adenocarcinoma, a short course of HBT administered before and during RT has been associated with a significant improvement in local control, reduction in disease progression and overall survival (Pilepich et al., 2001). Moreover, in the RTOG 92-02 trial, treatment of locally advanced PrCa using long-term HBT is superior to short-term HBT for all end points including local failure, PSA recurrence, and distance metastasis except survival (Table 2). However, for patients with Gleason score of 8 to 10, a survival advantage for long-term HBT plus RT was shown in these high-risk patients (Hanks et al., 2003; Horwitz et al., 2008). A specific survival benefit has been shown in several randomized trials compared with RT alone. In the RTOG 85-31 phase III trial, RT alone was compared with RT and Goserelin acetate (Zoladex). A decrease of specific mortality at 10 years from 22 to $16 \%$ (P1/40.0052) was demonstrated in the RT/HBT combination arm (Pilepich et al., 2005). In the EORTC 22863 trial, RT in combined with hormone therapy showed a $15 \%$ absolute specific survival advantage at 5 years compared to RT alone ( 94 versus $79 \%$,

Table 1 | Comparison of treatment outcome of RT vs RT/HBT (percentage).

\begin{tabular}{|c|c|c|c|c|c|c|c|c|c|c|c|c|}
\hline \multicolumn{3}{|c|}{ Local failure } & \multicolumn{3}{|c|}{ PSA failure } & \multicolumn{3}{|c|}{ Distant met. } & \multicolumn{3}{|c|}{ Overall survival } & \multirow[t]{2}{*}{ Reference } \\
\hline RT & $\mathrm{RT} / \mathrm{HBT}$ & $p$ Value & RT & RT/HBT & $p$ Value & RT & $\mathrm{RT} / \mathrm{HBT}$ & $p$ Value & RT & RT/HBT & $p$ Value & \\
\hline 38 & 23 & $<0.05$ & 91 & 69 & $<0.001$ & 39 & 24 & 0.0001 & 39 & 49 & 0.002 & Pilepich et al. (2005) \\
\hline 7 & 1 & $<0.05$ & 55 & 24 & $<0.05$ & 29 & 10 & $<0.05$ & 62 & 78 & 0.00002 & Bolla et al. (2002) \\
\hline
\end{tabular}

Table 2 | Comparison of treatment outcomes of short-term HBT (SHRT) and RT with long-term HBT and RT (LHRT; percentage).

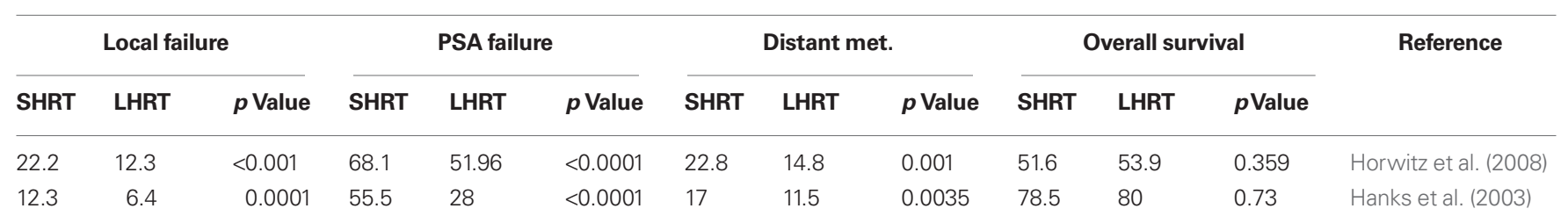


P1/40.0001; Bolla et al., 2002). In this trial, HBT consisted of a total androgen blockade with an anti-androgen (Cyproterone acetate) and a LH-RH agonist (Goserelin acetate) for 1 month followed by the LH-RH agonist alone (Goserelin acetate) for 3 years. HBT started on the first day of RT in the combination treatment arm. In the RTOG 86-10 trial, HBT began 2 months before the start of RT and continued during RT. HBT consisted of a total androgen blockade with flutamide and Goserelin acetate. In this study, specific mortality was also decreased in the combined treatment arm with 10 years of absolute benefit of $8 \%$ ( 77 versus $64 \%, \mathrm{P} 1 / 40.01$; Roach et al., 2008). This observation is confirmed in two other reports. HBT as the only therapy for locally advanced PrCa failed to provide as efficient disease control as combined treatments (Janoff et al., 2005; Widmark et al., 2009). As shown in the TROG 96.01 trial, for locally advanced prostate cancer, particularly in men without nodal metastases or pre-existing metabolic comorbidities that could be exacerbated by prolonged HBT, a short-term ( 6 months) treatment of neoadjuvant HBT combined with RT has been shown to be an effective treatment option (Denham et al., 2011).

Bicalutamide (Casodex), flutamide, and nilutamide are antagonists of AR and block androgen-regulated PrCa cell growth. In combination with a LH-RH agonist analog, bicalutamide has been shown to result in longer median survival than flutamide with better tolerance (Schellhammer et al., 1997a). Bicalutamide can also be used at low doses in the treatment of metastatic PrCa when used in combination with a LH-RH agonist, thereby providing a complete androgen blockade. Moreover, bicalutamide decreases the risk of fracture by maintaining bone mineral density, which is lost by LHRH analogs (Boccardo et al., 1999; Shahinian et al., 2005). Recently, a phase III study demonstrated an improved overall survival as achieved by using adjuvant high-dose bicalutamide following RT compared to RT alone (69.6 versus $57.6 \%, \mathrm{P} 1 / 40.03$ ) in a subgroup of patients with locally advanced PrCa after a median follow-up of 7.2 years (McLeod et al., 2006; See and Tyrrell, 2006). The gain in survival is comparable to the benefit from HBT by a LH-RH agonist in association with RT in the RTOG 85-31 study for highrisk $\mathrm{PrCa}$ (Pilepich et al., 2005). In two other clinical trial reports, the benefit of neoadjuvant HBT and RT is established compared to HBT as monotherapy (Table 3), thus further demonstrating synergism between HBT and RT in high-risk patients (Zagars et al., 2001; Widmark et al., 2009). Whether concomitant treatment with bicalutamide and RT results in an enhanced radiosensitivity of tumor cells responding to bicalutamide is still open to question.

Although not uniformly seen using clonogenic assays, there is evidence that HBT can sensitize prostate cancer cells to RT in in vitro models. The antagonistic radiation-drug interaction observed in LNCaP cells is of significance in RT-bicalutamide treatments directed against AR expressing tumors. PSA decreases with anti-androgen therapy with bicalutamide or flutamide in patients receiving combined androgen blockade. Serum PSA concentrations are decreased by $50 \%$ or more when $50 \%$ of patients are withdrawn from flutamide and $29 \%$ of patients are withdrawn from bicalutamide (Veldscholte et al., 1990; Schellhammer et al., 1997b). A supra-additive apoptosis with combination therapy has been shown in Dunning rat prostate tumors (Joon et al., 1997). This effect from the two modalities maximizes the apoptotic pathway for cellular death. However, concurrent anti-androgen treatment had no radiosensitization effect (Pollack et al., 2001). On the other hand, Zietman et al. (1997) using Shionogi SC-115 derived mouse cells in athymic male $\mathrm{NCr} / \mathrm{Sed}(\mathrm{nu} / \mathrm{nu})$ mice and in culture show androgen deprivation prior to radiation enhances the ability of irradiation to eradicate tumors in vivo. Androgen ablation can induced program celldeath in androgen-dependent prostate normal and cancerous cells (Isaacs et al., 1992). However, the HR cells induced by longterm anti-androgen treatment appeared more radioresistant than the androgen-sensitive 22RV1 cells (Wu et al., 2007). Therefore it is important to study the interaction between drug and ionizing radiation (IR) in PrCa. The relationship of AR and AR ligand with $\mathrm{RT}$ also requires further investigation.

In summary, there appears to be a clear benefit to combined therapy with HBT and RT in selected intermediate-risk and highrisk patients. However, there are both acute and long-term effects of hormone therapy that include the acceleration of cardiovascular disease, diabetes mellitus, and osteoporosis. One of the goals of understanding the molecular biology of $\mathrm{PrCa}$ is to evaluate the mechanism of the benefits of hormone therapy (cell adhesion modifier, etc.) and apply a targeted therapy with RT in order to temper the side effects of extended hormone treatment in patients with this disease. Novel therapies may mature and become validated with this approach to patient care.

\section{INTEGRIN AND EXTRACELLULAR MATRIX COMPONENT}

Extracellular matrix component and their receptors play an important role in cancer progression and metastasis (Hynes, 2002). Among these receptors, radiation appears to have a clear impact on integrin biology. Integrins are cell surface receptors which play an important role in oncogenesis, tumor aggression, and resistance to treatment as well as facilitating and promoting PrCa growth (Goel et al., 2009). The combination of integrin/cell adhesion inhibition and RT may become integral to improve patient outcome, especially for those patients with intermediate and high-risk features for tumor recurrence.

Integrin and its down stream signaling pathways have been shown to increase cell survival in response to IR (Onoda et al., 1994; Meineke et al., 2002; Abdollahi et al., 2005; Cordes et al., 2006; Park et al., 2008). Interactions between cells and ECM are

Table 3 | Comparison of treatment outcomes of HBT and HBT/RT (percentage).

\begin{tabular}{|c|c|c|c|c|c|c|c|c|c|c|c|c|}
\hline \multicolumn{3}{|c|}{ Local failure } & \multicolumn{3}{|c|}{ PSA failure } & \multicolumn{3}{|c|}{ Distant met. } & \multicolumn{3}{|c|}{ Overall survival } & \multirow[t]{2}{*}{ Reference } \\
\hline HBT & $\mathrm{RT} / \mathrm{HBT}$ & $p$ Value & HBT & $\mathrm{RT} / \mathrm{HBT}$ & $p$ Value & HBT & $\mathrm{RT} / \mathrm{HBT}$ & $p$ Value & HBT & RT/HBT & $p$ Value & \\
\hline 38 & 23 & $<0.05$ & 74.7 & 25.9 & $<0.001$ & 39 & 24 & 0.0001 & 60.6 & 70.4 & 0.004 & Widmark et al. (2009) \\
\hline
\end{tabular}


known to modulate sensitivity to radiation and drug in various types of tumors, such as breast, colon, ovaries, and prostate tumors (Fujita et al., 1995; Cance et al., 2000; Graff et al., 2001; Oktay et al., 2003). At low doses of RT cell adhesion molecules may be upregulated. Human lung carcinoma cells grown on fibronectin significantly elevated clonogenic survival as well as prolonged G2 arrest after RT (Cordes et al., 2003). Investigators also demonstrated that $\beta_{1}$ integrin mediated signaling through cytoplasmic domains is critical for efficient cell survival after RT (Cordes et al., 2006). Using a human breast cancer xenografts model, inhibition of integrin function by antibody (AIIB2) enhances RT efficacy suggesting $\beta_{1}$ integrin mediated radioresistance in breast cancer (Park et al., 2008). In renal carcinoma cells, adherence to collagen (I) enhances radioresistance through Akt dependent mechanism (Krasny et al., 2010). The negative influence in survival by integrin expression is seen in glottic cancer and cervical cancer (Choi et al., 2006; Hazelbag et al., 2007). IR upregulates the expression of $\beta_{1}$ integrins and subsequently the cell-matrix interaction of colorectal tumor cells in a dose dependent manner; most noted at low dose (Meineke et al., 2002). Combination therapy with $\alpha_{\mathrm{v}} \beta_{3}$ integrin antagonists and teletherapy appear beneficial in local tumor therapy. Cilengitide, a $\alpha_{\mathrm{v}} \beta_{3}$ integrin antagonist peptide, synergizes with radio-immunotherapy to increase efficacy and apoptosis in breast cancer cells (Burke et al., 2002). Similarly, Cao et al. (2006) have shown that combined treatment of $\alpha_{v}$ siRNA and irradiation leads to increased radiosensitivity. In PrCa, treatment of epithelial-versus mesenchymal-like cells by anti- $\alpha_{v}$ integrin blocking antibody significantly decreases stoma-cell induced radiation resistance (Josson et al., 2010). ADAM9 (a disintegrin and metalloprotease) appears to play a crucial role in radiation resistance in part by altering E-cadherin and integrin expression in $\mathrm{PrCa}$ cells (Josson et al., 2011). Cell adhesion hence has significant influence in cell survival with RT across many disease sites. We have demonstrated that high-doses of RT inhibit the expression of $\beta_{1}$ integrin in PrCa cells (Simon et al., 2005). In LNCaP cells stably transfected with $\beta_{3}$ integrin, $\alpha_{v} \beta_{3}$ integrin increased radiation resistance after clinically relevant doses of 2-10 Gy and enhanced anchorage-independent growth after 5 Gy irradiation as evaluated in the clonogenic assay and the anchorageindependent assays (Wang et al., 2007). Integrin function had no significant effect on AR expression. Hence the mechanism of resistance appears to be independent of receptor levels.

The biologic science of RT is revealing a provocative and developing relationship with cell adhesion. Although there is minimal influence on adhesion modulation in unirradiated tumor cells in the presence of androgen, bicalutamide significantly inhibited the adhesion response in irradiated cells thus reversing the effect of androgen (Wang et al., 2008). This suggests that bicalutamide may play a key role in adhesion modulation and possible tumor cell kill during RT, and, interestingly, may have little to no adhesion modulation effect in untreated tissue in the presence of androgen. This further suggests that patients may benefit from adhesion modulation during RT with very limited impact of this agent prior to treatment in the presence of androgen. This is an important concept in clinical trials as biological therapies are tested in a phase 1 environment that may or may not identify the appropriate environment for treatment application. Identifying the optimal microenvironmental strategy for targeted therapies will be crucial in validating their utility and establishing treatment sequence strategies moving forward.

As noted, we now know integrin expression is negatively affected by relatively high-dose RT. Simon et al. (2005) demonstrated that 2500 cGy delivered in a hypofractionation treatment platform inhibits $\beta_{1}$ integrin expression in DU-145 and PC-3 PrCa cells. This was not seen at lower doses of RT. Several reports indicate that the presence of $\beta_{3}$ and $\beta_{1}$ integrin in PrCa cells further promotes resistance to radiation treatment as well as promoting tumor growth kinetics. This implies that several biological factors may influence RT treatment response. Targeting these areas for additive therapies to facilitate cell kill during RT is an important area of translational science.

In addition to the integrin subunit presented above, growing reports are focusing on $\alpha_{\mathrm{v}}$ integrin and its effect on RT in cancers particularly as potential targets post-IR to inhibit angiogenesis in the tumor microenvironment. $\alpha_{v}$ integrin partners with $\beta_{1}, \beta_{3}$, and $\beta_{6}$ integrin subunits. Treatment with $\alpha_{v}$ integrin antagonist peptide and fractionated IR in PC-3 PrCa xenografts in BALB/c-nu/ nu mice leads to enhanced antiangiogenic and anti-tumor effect when compared with either treatment alone (Abdollahi et al., 2005). Meanwhile, targeting $\alpha_{v}$ could have direct effects on cancer cells, as several cancer cell types up-regulate $\alpha_{v}$ integrin post-IR (Wild-Bode et al., 2001; Smith and Giorgio, 2004). Upregulated $\alpha_{v}$ integrin could therefore be targeted in the primary tumor to enhance radiation effect (Cao et al., 2006). Interestingly, $\alpha_{\mathrm{v}} \beta_{3}$ integrin expression differs not only in cancer site, but also may vary in response to different qualities of IR such as heavy particles (Ogata et al., 2005).

\section{ANTIAPOPTOSIS MOLECULES SUCH AS bcl-2, p53, AND SURVIVIN}

Ionizing radiation-induced cell death can proceed via several pathways such as apoptosis, mitotic catastrophe, necrosis, and autophagy (Kim et al., 2006; Zhang et al., 2006; Kroemer et al., 2009). Apoptosis is an active process characterized by programmed cell death in which a cascade of events is triggered in response to cellular stress such as radiation (Nagata, 1997). Several lines of evidence suggest that progression from androgen-dependent to androgen-independent disease is associated with resistance to apoptosis and altered expression of caspases and expression of inhibitor of apoptosis (IAP) proteins (McEleny et al., 2002). Understanding which apoptotic pathways become altered and by what mechanism, for example genetic or epigenetic, may provide a rationale for targeting the cell death machinery in HR PrCa.

In $\mathrm{PrCa}$, changes in the expression level of several molecules have been identified in various components of the apoptotic cascade. For instance, bcl-2 over-expresses in patients with locally advanced or metastatic PrCa receiving hormonal therapy (Colombel et al., 1993; Krajewska et al., 1996) and bcl-2-overexpressing prostate carcinoma cell lines are associated with a reduced apoptotic response following treatment with various chemotherapeutic agents and IR (Kyprianou et al., 1997). Down-regulation of DAB2IP in PrCa cells showed resistance to IR-induced apoptosis due to a significantly higher levels of anti-apoptotic proteins bcl-2 and STAT3, and decrease in the expression levels of pro-apoptotic 
proteins caspase-3, caspase-8, and caspase-9 (Kong et al., 2010). P53, which controls the expression of several pro-apoptotic genes such as $B A X, C D K N 1 A$, and $M D M 2$, induces cell cycle arrest or apoptosis in response to DNA damage (Wang et al., 2004). TP53 mutations are uncommon in early invasive prostate carcinoma but occur frequently in advanced stages of disease (Navone et al., 1993). Expression of bcl-2 and p53 was associated with treatment failure after external beam RT (Scherr et al., 1999). Co-staining for p53 and bcl-2 is a potential biomarker for PrCa progression, poor prognosis and recurrence (Moul et al., 1996; Matsushima et al., 1997). Tissue microarrays of normal, and cancerous prostates have identified $b c l-2, F L I P$, clustrin (CLU), mothers against DPP homology 4 (SMAD4), death-associated protein (DAP), and p53-induced protein PIGPC1 (PERP) as down-regulated in PrCa (Yu et al., 2004). Interestingly, over expression of E2F1 in combination with RT treatment abrogated radiation-induced bcl-2 protein expression and caused a potent radiosensitizing effect, irrespective of p53 and AR functional status (Udayakumar et al., 2011). Such data highlights the importance of both pro-apoptotic and antiapoptotic molecules in prostate carcinogenesis and progression.

Survivin is a member of the IAP gene family whose expression is associated with conservation of cell division and direct inhibition of caspases (Altieri, 2006). Upregulation of survivin expression has been shown in glioblastoma, colon, and pancreatic cells (Chakravarti et al., 2004; Sreevalsan et al., 2009). Intratumoral injection of an antisense against survivin or of an adenovirus expressing a dominant negative form of survivin, T34A, inhibits tumor growth and enhances sensitivity to anti-androgen therapy (O'Connor et al., 2000; Zhang et al., 2005). Signaling pathways regulating survivin involve wild-type p53 and the Rb tumor suppressor that transcriptionally represses survivin (Jiang et al., 2004). Recent evidence suggests a strong relationship between survivin and PrCa radiation treatment. Over expression of survivin is associated with a significantly increased risk for the subsequent development of distant metastasis $(p=0.016)$ in early-stage $(\mathrm{T} 1 / \mathrm{T} 2)$ PrCa treated by definitive RT (Zhang et al., 2010a). Inhibition of cell survival and potentiated radiation cell killing by soy isoflavones in PrCa cells, in vitro and in vivo, is correlated with inhibition of survivin (Raffoul et al., 2007). While cytoplasmic over expression of survivin was associated with an increased rate of local progression in patients with locally advanced $\mathrm{PrCa}$, nuclear over expression of survivin was associated with improved overall and PrCa survival in patients treated on RTOG 8610 (Zhang et al., 2009). This might be the result from the complexity of survivin's role and differential responses to IR of heterogeneous PrCa cells. Some authors have argued that apoptosis is not the predominant form of PrCa cell death after exposure to IR (Steel, 2001). Bristow et al. have shown that terminal growth arrest instead of apoptosis is actually the dominant mechanism of radiation cell kill in $\mathrm{PrCa}$ cells (Bromfield et al., 2003). LNCaP cells supra-additive apoptosis does not translate into radiosensitization by clonogenic survival (Pollack et al., 2001). Other molecular mechanisms may play an important role in protecting PrCa cells from IR-induced toxicity. For example, melatonin expression fails to enhance PrCa cell death from IR duo to glutathione content. In contrast, melatonin significantly enhances hrTNFalpha induced cell death by downregulation of $\mathrm{Bcl}-2$ and survivin and stimulation of apoptosis under NF- $\kappa B$ inhibition (Sainz et al., 2008). Further study needs to be focused on the mechanism of IAP in regulating cell survival in response to IR.

\section{EPIGENETIC MODIFICATIONS - DNA METHYLATION}

In addition to classical genetic abnormalities, epigenetic modifications have emerged as an important issue in the molecular pathology of PrCa (Perry et al., 2006). So far, DNA methylation, histone modification and genomic imprinting are three major mechanisms for epigenetic modifications identified in PrCa. We focus on DNA methylation in this review because: (1) DNA methylation directly modifies specific gene transcription which subsequently controls the gene related cellular function (i.e., GSTP1, AR; Jarrard et al., 1998; Kinoshita et al., 2000; Yegnasubramanian et al., 2004; Meiers et al., 2007); (2) histone modification by methylation at the residue lysine by EZH2 is linked to advanced hormone resistant metastatic PrCa (Kirmizis et al., 2004); and (3) genomic imprinting can be controlled by DNA methylation (i.e., p57 tumor suppressor gene, TSG; Lodygin et al., 2005).

DNA methylation is defined as an addition of a methyl $\left(-\mathrm{CH}_{3}\right)$ group at the $5^{\prime}$-carbon on cytosine nucleotide adjacent to a guanine (CpG; Weber and Schubeler, 2007). DNA methylation is processed by various conserved enzymes named DNA MTases (DNMTs) that transfer $-\mathrm{CH}_{3}$ group from $S$-adenosylmethionine (SAM) to covalently bind at cytosine residues in the promoter of a target gene. SAM is produced through a folate and cobalamin dependent pathway (Dobosy et al., 2007). DNA hypermethylation is one of the known epigenetic modifications and plays an important role in the down-regulation of gene expression critical for protection against $\mathrm{PrCa}$ (Esteller, 2005). It is associated with an inactive chromatin state and is often with repressed gene expression activity (Klose and Bird, 2006; Weber and Schubeler, 2007). Abnormal changes in Global DNA methylation have been linked to initiation of various cancer cells (Baylin and Ohm, 2006; Weidman et al., 2007).

The function of DNA methylation is diversified in a variety of tissues including normal and neoplastic cells. Disruption of DNA methylation by inactivation of DNMTs is lethal to embryo in early development (Li et al., 1992). In cancer cells, DNA methylation has a divergent effect. Hypermethylation occurs in the promoters of tumor suppressor and other genes resulting in silencing the associated gene in the absence of a mutation or deletion. In PrCa, the DNMT1 has 2- to 3-fold higher enzymatic activities compared to that in BPH and normal tissue (Patra et al., 2002). DNMT2 and DNMT3a are upregulated in HR PrCa cells indicating the importance of alternation of methylation for development of androgen resistance PrCa (Pang et al., 2006).

Methylation of $\mathrm{AR}$ promoter $\mathrm{CpG}$ island is associated with the development of HR PrCa. Jarrard et al. (1998) using Southern Blot with methylation-sensitive restriction enzymes and methylation-specific PCR found aberrant methylation in the AR negative cells DU-145 and DuPro while in AR positive cells LNCaP shows no methylation. Treatment of DuPro with a demethylating agent 5-aza-2' deoxycytidine induces the reexpression of AR RNA (Jarrard et al., 1998).

So far, more than 50 genes have been reported to be hypermethylated in PrCa (Li et al., 2004; Nelson et al., 2007). Many of these genes are often mutated or deleted in PrCa suggesting the 
alteration of gene expression resulted from epigenetic silencing and genetic mutation. Among these, roughly a dozen are consistently affected in the vast majority of cases. These gene products involve the various molecules that directly control DNA damage repair (GSTP1), tumor suppressor, cell cycle control, cell adhesion, and signal transduction.

Analysis of the methylation of genes such as RASSF1A, RARB2, $A P C$, and GSTP1 (Florl et al., 2004) or GSTP1, APC, and MDR1 (Enokida et al., 2005) clearly discriminates between benign and cancerous tumors in the prostate. Hypermethylation silencing of TSG increases mutation rates and tumor progression (Jones and Baylin, 2002). Whereas hypermethylation of specific genes is evidently associated with an early phase of PrCa development, global DNA hypomethylation may be related to PrCa progression. Metastatic cases are characterized by pronounced decreases in overall methylcytosine content and, in particular, hypomethylation of LINE-1 retrotransposons, which are almost completely methylated in normal cells (Florl et al., 2004). Localized cancers may even display an increase in overall methylation at cytosine, despite a low degree of retroelement hypomethylation (Yegnasubramanian et al., 2008). Likewise, over expression of cancer-testis antigen genes, which is regularly associated with hypomethylation of their promoters, is largely restricted to advanced stages of prostate adenocarcinoma (Yegnasubramanian et al., 2008). The consistency with which large-scale hypomethylation is observed in metastatic cases suggests that the mechanisms maintaining methylation at retroelements and other normally methylated sequences are regularly disturbed during PrCa progression.

Recent data also demonstrate a relationship between DNA methylation and response to RT. Point mutations in Keap1 gene lead to non-conservative amino acid substitutions in PrCa cells, novel transcriptional and posttranscriptional mechanisms of Keap1 inactivation, such as promoter CpG island hypermethylation and aberrant splicing of Keap1 in DU-145 cells, enhances Nrf2 activity and subsequently prevents cell sensitivity to radiation-induced cell death (Zhang et al., 2010b). In breast cancer cells, the loss of Nrf2 increases radiation sensitivity via regulation of antioxidant DNA responsive element ( $\mathrm{McD}$ onald et al., 2010). A single methylated gene can affect radiation sensitivity. In cervical cancer, methylation of p73 (tumor protein 73) increased significantly. Reactivation of p73 expression by demethylation treatment revealed the role of methylation in the regulation of p73 expression and plays an important role in regulation of cellular radiosensitivity (Liu et al., 2004). Another important gene that can change cell sensitivity to IR, ATM, was also identified as a vital component of the signal transduction pathway activated by DNA damage (Shiloh, 2003; Lavin et al., 2005). U87 glioma cells with lower levels of ATM were more sensitive to IR (42-fold) than T98G glioma cells exhibiting normal levels of ATM protein. The ATM promoter in U87 cells was methylated. Demethylation treatment increases ATM protein levels in U87 cells and decreases their radiosensitivity (Roy et al., 2006). The methylation status of many other genes was also associated with radiosensitivity, e.g., suppressor of cytokine signaling 1 (SOCS1), suppressor of cytokine signaling 3 (SOCS3), and death-associated protein kinase (DAPK; Zhou et al., 2007; Leung et al., 2008).

\section{PrCa METASTASIS FOLLOWING RADIATION}

One of the challenges in treating advanced PrCa is whether or not radiopharmaceuticals could eradicate tumor cells that have metastasized to the bone microenvironment. Micrometastatic cells have been identified in bone marrow in an onco-niche and studies are needed to understand if such are resistant to radiation treatment (Tu et al., 2010). Multiple regulatory networks contribute to proliferation of PrCa cells, survival, metastasis, and homing of $\mathrm{PrCa}$ cells to bone (Altieri et al., 2009; Pratap et al., 2011). In addition to the factors described above, a transcriptional based regulatory network involves the bone essential transcription factor, Runx2, which is abnormally expressed in PrCa cells and has been correlated with metastatic bone disease (Akech et al., 2010; Baniwal et al., 2010). Runx2 expression is restricted to mesenchymal stem cells and marks them for commitment to the osteogenic lineage cells, but is absent from normal epithelial cells of the prostate glands (Zaidi et al., 2007). The highest levels of Runx2 are observed in the most aggressive human metastatic cell lines producing both osteoclastic and osteoblastic lesions in prostate tumors that metastasize to bone (Yang et al., 2001; Roudier et al., 2004; Akech et al., 2010). However, in studies using the conditional PTEN deletion mouse model, cancer associated fibroblasts were isolated from the adenocarcinomas and a signature of genes identified that included high Runx2 expression levels (Liao et al., 2010). These observations suggest that Runx 2 could support tumor growth, progression, and metastasis.

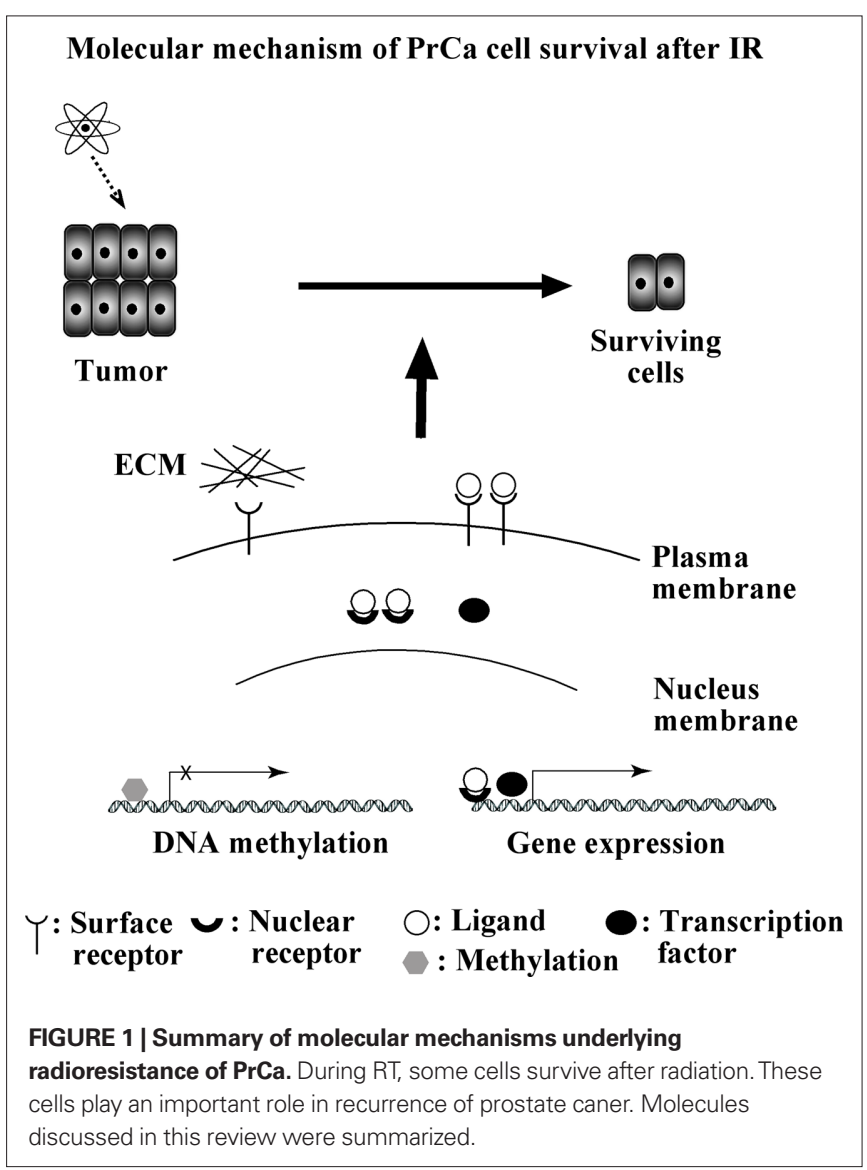


Runx2 functions as a tumor suppressor in normal osteoblast, and but its deregulated expression and activity in PrCa cells leads to activation of numerous genes related to metastasis. Direct targets of Runx2 include matrix metalloproteinases, survivin, integrins, and bone matrix proteins that have been correlated with metastasis (Lim et al., 2010; Rucci and Teti, 2010). Runx2 also enhances cell growth and responses to androgen, TGF $\beta$ and BMP by forming complexes with hormone receptors and SMAD intracellular receptors of TGF $\beta / \mathrm{BMP}$ signaling that promote tumor growth (Baniwal et al., 2010; van der Deen et al., 2010). Another component of a Runx2 regulatory network is the recently identified microRNA, miR-203 (Saini et al., 2010). This miR is specifically decreased in highly metastatic PrCa cells and targets numerous pro-metastatic genes including Runx2. Thus, Runx2 has been clearly established as a mediator of the metastatic properties of PrCa cell that affects multiple levels of activity of PrCa cells. Runx2 is a viable candidate for therapy, particularly for androgen-independent tumors and cancer cells resistant to RT. Indeed, in mouse models of prostate tumor growth in bone, shRunx2 knockdown prevented tumor growth in bone and the accompanying metastatic bone disease (Pratap et al., 2008; Akech et al., 2010).

\section{CONCLUSION}

In summary, process improvements in patient care continue to be important in the RT treatment of PrCa. Although we have been successful in improving patient outcome with both low and selected intermediate-risk PrCa patients, we continue to need improved strategies for patient care in more advanced intermediate and high-risk patients. Since the disease remains largely chemotherapy naïve, $\mathrm{PrCa}$ is a good model to explore alternatives in patient care management with RT. As seen, cell adhesion modulation, signaling pathway evaluation, and epigenetic models such as DNA methylation may prove to be important adjuncts in the clinical RT management of these patients (Figure 1). Alternatives to hormone management may likewise become important in selected intermediate-risk patients as we uncover latent risks of diabetes, osteoporosis, and other secondary events associated with protracted hormone management in these patients. Delaying hormone treatment in lieu of a more targeted strategy with RT may be advantageous in the next generation of PrCa patients. In addition to the molecules mentioned in this review, many other molecules (i.e., EGF, IGF, microRNAs) and their signaling pathways have been linked with PrCa progression and resistance to RT. Continued integration of basic and translational science strategies into our current practice management will likely prove helpful in the future care of our patients.

\section{ACKNOWLEDGMENTS}

We appreciate Dr. Jesse Aronowitz for his comment on the paper. We also thank Karen Heine and Fran Laurie for their help during revision. The work is supported from NIH program project PO1 CA 140043 (PI: Dario C. Altieri).

\section{REFERENCES}

Abdollahi, A., Griggs, D. W., Zieher, H., Roth, A., Lipson, K. E., Saffrich, R., Grone, H. J., Hallahan, D. E., Reisfeld, R. A., Debus, J., Niethammer, A. G., and Huber, P. E. (2005). Inhibition of $\alpha v \beta 3$ integrin survival signaling enhances antiangiogenic and antitumor effects of radiotherapy. Clin. Cancer Res. 11, 6270-6279.

Akech, J., Wixted, J. J., Bedard, K., van der Deen, M., Hussain, S., Guise, T. A., van Wijnen, A. J., Stein, J. L., Languino, L. R., Altieri, D. C., Pratap, J., Keller, E., Stein, G. S., and Lian, J. B. (2010). Runx2 association with progression of prostate cancer in patients: mechanisms mediating bone osteolysis and osteoblastic metastatic lesions. Oncogene 29, 811-821.

Allen, G. W., Howard, A. R., Jarrard, D. F., and Ritter, M.A. (2007). Management of prostate cancer recurrences after radiation therapy-brachytherapy as a salvage option. Cancer 110, 1405-1416.

Altieri, D. C. (2006). Targeted therapy by disabling crossroad signaling networks: the survivin paradigm. Mol. Cancer Ther. 5, 478-482.

Altieri, D. C., Languino, L. R., Lian, J. B., Stein, J. L., Leav, I., van Wijnen, A. J., Jiang, Z., and Stein, G. S. (2009).
Prostate cancer regulatory networks. J. Cell. Biochem. 107, 845-852.

Baniwal, S. K., Khalid, O., Gabet, Y., Shah, R. R., Purcell, D. J., Mav, D., Kohn-Gabet, A. E., Shi, Y., Coetzee, G. A., and Frenkel, B. (2010). Runx2 transcriptome of prostate cancer cells: insights into invasiveness and bone metastasis. Mol. Cancer 9, 258.

Baylin, S. B., and Ohm, J. E. (2006). Epigenetic gene silencing in cancer a mechanism for early oncogenic pathway addiction? Nat. Rev. Cancer 6, 107-116.

Belka, C., Jendrossek, V., Pruschy, M., Vink, S., Verheij, M., and Budach, W. (2004). Apoptosis-modulating agents in combination with radiotherapycurrent status and outlook. Int. J. Radiat. Oncol. Biol. Phys. 58, 542-554. Boccardo, F., Rubagotti, A., Barichello, M., Battaglia, M., Carmignani, G., Comeri, G., Conti, G., Cruciani, G., Dammino, S., Delliponti, U., Ditonno, P., Ferraris, V., Lilliu, S., Montefiore, F., Portoghese, F., and Spano, G. (1999). Bicalutamide monotherapy versus flutamide plus goserelin in prostate cancer patients: results of an Italian Prostate Cancer Project study. J. Clin. Oncol. 17, 2027-2038.

Bolla, M., Collette, L., Blank, L., Warde, P., Dubois, J. B., Mirimanoff, R. O., Storme, G., Bernier, J., Kuten, A.,
Sternberg, C., Mattelaer, J., Lopez Torecilla, J., Pfeffer, J. R., Lino Cutajar, C., Zurlo, A., and Pierart, M. (2002). Long-term results with immediate androgen suppression and external irradiation in patients with locally advanced prostate cancer (an EORTC study): a phase III randomised trial. Lancet 360, 103-106.

Brenner, D. J., and Hall, E. J. (1999). Fractionation and protraction for radiotherapy of prostate carcinoma. Int. J. Radiat. Oncol. Biol. Phys. 43, 1095-1101.

Bromfield, G. P., Meng, A., Warde, P., and Bristow, R. G. (2003). Cell death in irradiated prostate epithelial cells: role of apoptotic and clonogenic cell kill. Prostate Cancer Prostatic Dis. 6, 73-85.

Burke, P. A., DeNardo, S. J., Miers, L. A., Lamborn, K. R., Matzku, S., and DeNardo, G. L. (2002). Cilengitide targeting of $\alpha v \beta 3$ integrin receptor synergizes with radioimmunotherapy to increase efficacy and apoptosis in breast cancer xenografts. Cancer Res. 62, 4263-4272.

Cance, W. G., Harris, J. E., Iacocca, M. V., Roche, E., Yang, X., Chang, J., Simkins, S., and $\mathrm{Xu}$, L. (2000). Immunohistochemical analyses of focal adhesion kinase expression in benign and malignant human breast and colon tissues: correlation with preinvasive and invasive phenotypes. Clin. Cancer Res. 6, 2417-2423.

Cao, Q., Cai, W., Li, T., Yang, Y., Chen, K., Xing, L., and Chen, X. (2006). Combination of integrin siRNA and irradiation for breast cancer therapy. Biochem. Biophys. Res. Commun. 351, 726-732.

Catton, C., Milosevic, M., Warde, P., Bayley, A., Crook, J., Bristow, R., and Gospodarowicz, M. (2003). Recurrent prostate cancer following external beam radiotherapy: follow-up strategies and management. Urol. Clin. North Am. 30, 751-763.

Chakravarti, A., Zhai, G. G., Zhang, M., Malhotra, R., Latham, D. E., Delaney, M. A., Robe, P., Nestler, U., Song, Q., and Loeffler, J. (2004). Survivin enhances radiation resistance in primary human glioblastoma cells via caspase-independent mechanisms. Oncogene 23, 7494-7506.

Choi, S. H., Cho, K. J., Nam, S. Y., Lee, S. W., Kang, J., and Kim, S. Y. (2006). Clinical significance of $\beta 1$ integrin expression as a prediction marker for radiotherapy in early glottic carcinoma. Laryngoscope 116, 1228-1231. Coblentz, T. R., Bissonette, E. A., Williams, K. R., and Theodorescu, D. (2002). Multimodality radiotherapy and androgen ablation in the treatment of clinically localized prostate cancer: 
early results in high risk patients. Prostate Cancer Prostatic Dis. 5, 219-225.

Colombel, M., Symmans, F., Gil, S., O’Toole, K. M., Chopin, D., Benson, M., Olsson, C. A., Korsmeyer, S., and Buttyan, R. (1993). Detection of the apoptosis-suppressing oncoprotein bcl-2 in hormone-refractory human prostate cancers. Am. J. Pathol. 143, 390-400.

Cordes, N., Blaese, M. A., Plasswilm, L., Rodemann, H. P., and Van Beuningen, D. (2003). Fibronectin and laminin increase resistance to ionizing radiation and the cytotoxic drug Ukrain in human tumour and normal cells in vitro. Int. J. Radiat. Biol. 79, 709-720.

Cordes, N., Seidler, J., Durzok, R., Geinitz, H., and Brakebusch, C. (2006). $\beta 1$-integrin-mediated signaling essentially contributes to cell survival after radiation-induced genotoxic injury. Oncogene 25, 1378-1390.

Dehm, S. M., and Tindall, D. J. (2006). Molecular regulation of androgen action in prostate cancer. J. Cell. Biochem. 99, 333-344.

Denham, J. W., Steigler, A., Lamb, D. S., Joseph, D., Turner, S., Matthews, J., Atkinson, C., North, J., Christie, D., Spry, N. A., Tai, K. H., Wynne, C., and D’Este, C. (2011). Short-term neoadjuvant androgen deprivation and radiotherapy for locally advanced prostate cancer: 10-year data from the TROG 96.01 randomised trial. Lancet Oncol. $12,451-459$.

Dobosy, J. R., Roberts, J. L., Fu, V. X., and Jarrard, D. F. (2007). The expanding role of epigenetics in the development, diagnosis and treatment of prostate cancer and benign prostatic hyperplasia. J. Urol. 177, 822-831.

Edge, S. B., Byrd, D. R., Compton, C. C., Fritz, A. G., Greene, F. L., and Trotti, A. (2010). AJCC Cancer Staging Manual. New York, NY: Springer.

Enokida, H., Shiina, H., Urakami, S., Igawa, M., Ogishima, T., Li, L. C., Kawahara, M., Nakagawa, M., Kane, C. J., Carroll, P. R., and Dahiya, R. (2005). Multigene methylation analysis for detection and staging of prostate cancer. Clin. Cancer Res. 11, 6582-6588.

Esteller, M. (2005). DNA methylation and cancer therapy: new developments and expectations. Curr. Opin. Oncol. $17,55-60$.

Feldman, B. J., and Feldman, D. (2001). The development of androgenindependent prostate cancer. Nat. Rev. Cancer 1, 34-45.

FitzGerald, T. J., Simon, E., and Meyer, J. (2004). Prostate carcinoma: opportunities for translational research. J. Cell. Biochem. 91, 433-442.

Florl, A. R., Steinhoff, C., Muller, M., Seifert, H. H., Hader, C., Engers, R.,
Ackermann, R., and Schulz, W. A. (2004). Coordinate hypermethylation at specific genes in prostate carcinoma precedes LINE-1 hypomethylation. $B r$. J. Cancer 91, 985-994.

Fowler, J. F., Ritter, M. A., Chappell, R. J., and Brenner, D. J. (2003). What hypofractionated protocols should be tested for prostate cancer? Int. J. Radiat. Oncol. Biol. Phys. 56, 1093-1104.

Fujita, S., Watanabe, M., Kubota, T., Teramoto, T., and Kitajima, M. (1995). Alteration of expression in integrin beta 1-subunit correlates with invasion and metastasis in colorectal cancer. Cancer Lett. 91, 145-149.

Garzotto, M., Haimovitz-Friedman, A., Liao, W. C., White-Jones, M., Huryk, R., Heston, W. D., Cardon-Cardo, C., Kolesnick, R., and Fuks, Z. (1999). Reversal of radiation resistance in LNCaP cells by targeting apoptosis through ceramide synthase. Cancer Res. 59, 5194-5201.

Gleason, D. F., and T.V.U.R. Group. (1997). "Histologic grading and staging of prostatic carcinoma," in Urologic Pathology, ed. M. Tannenbaum (Philadelphia, PA: Lea \& Febiger), 171-187.

Goel, H. L., Alam, N., Johnson, I. N., and Languino, L. R. (2009). Integrin signaling aberrations in prostate cancer. Am. J. Transl. Res. 1, 211-220.

Graff, J. R., Deddens, J. A., Konicek, B. W., Colligan, B. M., Hurst, B. M., Carter, H. W., and Carter, J. H. (2001). Integrinlinked kinase expression increases with prostate tumor grade. Clin. Cancer Res. 7, 1987-1991.

Hanks, G. E., Pajak, T. F., Porter, A., Grignon, D., Brereton, H., Venkatesan, V., Horwitz, E. M., Lawton, C., Rosenthal, S. A., Sandler, H. M., and Shipley, W. U. (2003). Phase III trial of long-term adjuvant androgen deprivation after neoadjuvant hormonal cytoreduction and radiotherapy in locally advanced carcinoma of the prostate: the Radiation Therapy Oncology Group Protocol 92-02. J. Clin. Oncol. 21, 3972-3978.

Hazelbag, S., Kenter, G. G., Gorter, A., Dreef, E. J., Koopman, L. A., Violette, S. M., Weinreb, P. H., and Fleuren, G. J. (2007). Overexpression of the $\alpha v \beta 6$ integrin in cervical squamous cell carcinoma is a prognostic factor for decreased survival. J. Pathol. 212, 316-324.

Heinlein, C. A., and Chang, C. (2004). Androgen receptor in prostate cancer. Endocr. Rev. 25, 276-308.

Higuchi, Y. (2003). Chromosomal DNA fragmentation in apoptosis and necrosis induced by oxidative stress. Biochem. Pharmacol. 66, 1527-1535.

Horwitz, E. M., Bae, K., Hanks, G. E., Porter, A., Grignon, D. J., Brereton,
H. D., Venkatesan, V., Lawton, C. A., Rosenthal, S. A., Sandler, H. M., and Shipley, W. U. (2008). Ten-year follow-up of radiation therapy oncology group protocol 92-02: a phase III trial of the duration of elective androgen deprivation in locally advanced prostate cancer. J. Clin. Oncol. 26, 2497-2504.

Hynes, R. O. (2002). Integrins: bidirectional, allosteric signaling machines. Cell 110, 673-687.

Isaacs, J. T. (1999). The biology of hormone refractory prostate cancer. Why does it develop? Urol. Clin. North Am. 26, 263-273.

Isaacs, J. T., Lundmo, P. I., Berges, R., Martikainen, P., Kyprianou, N., and English, H. F. (1992). Androgen regulation of programmed death of normal and malignant prostatic cells. J. Androl. 13, 457-464.

Janoff, D. M., Peterson, C., S. MongoueTchokote, Peters, L., Beer, T. M., Wersinger, E. M., Mori, M., and Garzotto, M. (2005). Clinical outcomes of androgen deprivation as the sole therapy for localized and locally advanced prostate cancer. BJU Int. 96 , 503-507.

Jarrard, D. F., Kinoshita, H., Shi, Y., Sandefur, C., Hoff, D., Meisner, L. F., Chang, C., Herman, J. G., Isaacs, W. B., and Nassif, N. (1998). Methylation of the androgen receptor promoter CpG island is associated with loss of androgen receptor expression in prostate cancer cells. Cancer Res. 58, 5310-5314.

Jemal, A., Bray, F., Center, M. M., Ferlay, J., Ward, E., and Forman, D. (2011). Global cancer statistics. CA Cancer J. Clin. 61, 69-90.

Jemal, A., Siegel, R., Xu, J., and Ward, E. (2010). Cancer statistics, 2010. CA Cancer J. Clin. 60, 277-300.

Jiang, Y., Saavedra, H. I., Holloway, M. P., Leone, G., and Altura, R. A. (2004). Aberrant regulation of survivin by the RB/E2F family of proteins. J. Biol. Chem. 279, 40511-40520.

Jones, P. A., and Baylin, S. B. (2002). The fundamental role of epigenetic events in cancer. Nat. Rev. Genet. 3, 415-428.

Joon, D. L., Hasegawa, M., Sikes, C., Khoo, V. S., Terry, N. H., Zagars, G. K., Meistrich, M. L., and Pollack, A. (1997). Supraadditive apoptotic response of R3327-G rat prostate tumors to androgen ablation and radiation. Int. J. Radiat. Oncol. Biol. Phys. 38, 1071-1077.

Josson, S., Anderson, C. S., Sung, S. Y., Johnstone, P. A., Kubo, H., Hsieh, C. L., Arnold, R., Gururajan, M., Yates, C., and Chung, L.W. (2011). Inhibition of ADAM9 expression induces epithelial phenotypic alterations and sensitizes human prostate cancer cells to radiation and chemotherapy. Prostate 71, 232-240.

Josson, S., Matsuoka, Y., Chung, L. W., Zhau, H. E., and Wang, R. (2010). Tumor-stroma co-evolution in prostate cancer progression and metastasis. Semin. Cell Dev. Biol. 21, 26-32.

Kan, Z., Jaiswal, B. S., Stinson, J., Janakiraman, V., Bhatt, D., Stern, H. M., Yue, P., Haverty, P. M., Bourgon, R., Zheng, J., Moorhead, M., Chaudhuri, S., Tomsho, L. P., Peters, B. A., Pujara, K., Cordes, S., Davis, D. P., Carlton, V. E., Yuan, W., Li, L., Wang, W., Eigenbrot, C., Kaminker, J. S., Eberhard, D. A., Waring, P., Schuster, S. C., Modrusan, Z., Zhang, Z., Stokoe, D., de Sauvage, F. J., Faham, M., and Seshagiri, S. (2010). Diverse somatic mutation patterns and pathway alterations in human cancers. Nature 466, 869-873.

Kim, K. W., Mutter, R. W., Cao, C., Albert, J. M., Freeman, M., Hallahan, D. E., and $\mathrm{Lu}$, B. (2006). Autophagy for cancer therapy through inhibition of pro-apoptotic proteins and mammalian target of rapamycin signaling. $J$. Biol. Chem. 281, 36883-36890.

Kinoshita, H., Shi, Y., Sandefur, C., Meisner, L. F., Chang, C., Choon, A., Reznikoff, C. R., Bova, G. S., Friedl, A., and Jarrard, D. F. (2000). Methylation of the androgen receptor minimal promoter silences transcription in human prostate cancer. Cancer Res. 60, 3623-3630.

Kirmizis, A., Bartley, S. M., Kuzmichev, A., Margueron, R., Reinberg, D., Green, R., and Farnham, P. J. (2004). Silencing of human polycomb target genes is associated with methylation of histone H3 Lys 27. Genes Dev. 18, 1592-1605.

Klose, R. J., and Bird, A. P. (2006). Genomic DNA methylation: the mark and its mediators. Trends Biochem. Sci. 31, 89-97.

Kong, Z., Xie, D., Boike, T., Raghavan, P., Burma, S., Chen, D. J., Habib, A. A., Chakraborty, A., Hsieh, J. T., and Saha, D. (2010). Downregulation of human DAB2IP gene expression in prostate cancer cells results in resistance to ionizing radiation. Cancer Res. 70, 2829-2839.

Krajewska, M., Krajewski, S., Epstein, J. I., Shabaik, A., Sauvageot, J., Song, K., Kitada, S., and Reed, J. C. (1996). Immunohistochemical analysis of bcl2, bax, bcl-X, and mcl-1 expression in prostate cancers. Am. J. Pathol. 148, 1567-1576.

Krasny, L., Shimony, N., Tzukert, K., Gorodetsky, R., Lecht, S., Nettelbeck, D. M., and Haviv, Y. S. (2010). An in-vitro tumour microenvironment model using adhesion to type I collagen reveals Akt-dependent radiation resistance in renal cancer 
cells. Nephrol. Dial. Transplant. 25, 373-380.

Kroemer, G., Galluzzi, L., Vandenabeele,P., Abrams, J., Alnemri, E. S., Baehrecke, E. H., Blagosklonny, M. V., El-Deiry, W. S., Golstein, P., Green, D. R., Hengartner, M., Knight, R. A., Kumar, S., Lipton, S. A., Malorni, W., Nunez, G., Peter, M. E., Tschopp, J., Yuan, J., Piacentini, M., Zhivotovsky, B., and Melino, G. (2009). Classification of cell death: recommendations of the Nomenclature Committee on Cell Death 2009. Cell Death Differ. 16, 3-11.

Kyprianou, N., King, E. D., Bradbury, D., and Rhee, J. G. (1997). Bcl-2 overexpression delays radiation-induced apoptosis without affecting the clonogenic survival of human prostate cancer cells. Int. J. Cancer 70, 341-348.

Lavin, M. F., Birrell, G., Chen, P., Kozlov, S., Scott, S., and Gueven, N. (2005). ATM signaling and genomic stability in response to DNA damage. Mutat. Res. 569, 123-132.

Leung, R. C., Liu, S. S., Chan, K. Y., Tam, K. F., Chan, K. L., Wong, L. C., and Ngan, H.Y. (2008). Promoter methylation of death-associated protein kinase and its role in irradiation response in cervical cancer. Oncol. Rep. 19, 1339-1345.

Li, E., Bestor, T. H., and Jaenisch, R. (1992). Targeted mutation of the DNA methyltransferase gene results in embryonic lethality. Cell 69, 915-926.

Li, L. C., Okino, S. T., and Dahiya, R. (2004). DNA methylation in prostate cancer. Biochim. Biophys. Acta 1704, 87-102.

Liao, C. P., Adisetiyo, H., Liang, M., and Roy-Burman, P. (2010). Cancerassociated fibroblasts enhance the gland-forming capability of prostate cancer stem cells. Cancer Res. 70, 7294-7303.

Lim, M., Zhong, C., Yang, S., Bell, A. M., Cohen, M. B., and Roy-Burman, P. (2010). Runx2 regulates survivin expression in prostate cancer cells. Lab. Invest. 90, 222-233.

Lin, X., Zhang, F., Bradbury, C. M., Kaushal, A., Li, L., Spitz, D. R., Aft, R. L., and Gius, D. (2003). 2-DeoxyD-glucose-induced cytotoxicity and radiosensitization in tumor cells is mediated via disruptions in thiol metabolism. Cancer Res. 63, 3413-3427.

Liu, S. S., Leung, R. C., Chan, K. Y., Chiu, P. M., Cheung, A. N., Tam, K. F., Ng, T. Y., Wong, L. C., and Ngan, H. Y. (2004). p73 expression is associated with the cellular radiosensitivity in cervical cancer after radiotherapy. Clin. Cancer Res. 10, 3309-3316.

Lodygin, D., Epanchintsev, A., Menssen, A., Diebold, J., and Hermeking, $\mathrm{H}$. (2005). Functional epigenomics iden- tifies genes frequently silenced in prostate cancer. Cancer Res. 65, 4218-4227.

Matsushima, H., Kitamura, T., Goto, T., Hosaka, Y., Homma, Y., and Kawabe, K. (1997). Combined analysis with Bcl-2 and P53 immunostaining predicts poorer prognosis in prostatic carcinoma. J. Urol. 158, 2278-2283.

McDonald, J. T., Kim, K., Norris, A. J., Vlashi, E., Phillips, T. M., Lagadec, C., Della Donna, L., Ratikan, J., Szelag, H., Hlatky, L., and McBride, W.H. (2010). Ionizing radiation activates the $\mathrm{Nrf} 2$ antioxidant response. Cancer Res. 70, 8886-8895.

McEleny, K. R., Watson, R. W., Coffey, R. N., O'Neill, A. J., and Fitzpatrick, J. M. (2002). Inhibitors of apoptosis proteins in prostate cancer cell lines. Prostate 51, 133-140.

McLeod, D. G., See, W. A., Klimberg, I., Gleason, D., Chodak, G., Montie, J., Bernstein, G., Morris, C., and Armstrong, J. (2006). The bicalutamide $150 \mathrm{mg}$ early prostate cancer program: findings of the North American trial at 7.7-year median followup. J. Urol. 176, 75-80.

Meiers, I., Shanks, J. H., and Bostwick, D. G. (2007). Glutathione S-transferase pi (GSTP1) hypermethylation in prostate cancer: review 2007. Pathology 39 , 299-304.

Meineke, V., Gilbertz, K. P., Schilperoort, K., Cordes, N., Sendler, A., Moede, T., and van Beuningen, D. (2002). Ionizing radiation modulates cell surface integrin expression and adhesion of COLO- 320 cells to collagen and fibronectin in vitro. Strahlenther. Onkol. 178, 709-714.

Mimeault, M., and Batra, S. K. (2006). Recent advances on multiple tumorigenic cascades involved in prostatic cancer progression and targeting therapies. Carcinogenesis 27, 1-22.

Miralbell, R., Roberts, S. A., Zubizarreta, E., and Hendry, J. H. (2011). Dosefractionation sensitivity of prostate cancer deduced from radiotherapy outcomes of 5,969 patients in seven international institutional datasets: alpha/beta $=1.4(0.9-2.2)$ Gy. Int. J. Radiat. Oncol. Biol. Phys. 1-8.

Mishra, K. P. (2004). Cell membrane oxidative damage induced by gammaradiation and apoptotic sensitivity. J. Environ. Pathol. Toxicol. Oncol. 23, 61-66.

Moul,J.W., Bettencourt, M.C., Sesterhenn, I. A., Mostofi, F. K., McLeod, D. G., Srivastava, S., and Bauer, J. J. (1996). Protein expression of $\mathrm{p} 53$, bcl-2, and KI-67 (MIB-1) as prognostic biomarkers in patients with surgically treated, clinically localized prostate cancer. Surgery 120, 159-166.

Nagata, S. (1997). Apoptosis by death factor. Cell 88, 355-365.
Navone, N. M., Troncoso, P., Pisters, L. L., Goodrow, T. L., Palmer, J. L., Nichols, W. W., von Eschenbach, A. C., and Conti, C. J. (1993). p53 protein accumulation and gene mutation in the progression of human prostate carcinoma. J. Natl. Cancer Inst. 85 , 1657-1669.

Nelson, W. G., Yegnasubramanian, S., Agoston, A. T., Bastian, P. J., Lee, B. H., Nakayama, M., and De Marzo, A. M. (2007). Abnormal DNA methylation, epigenetics, and prostate cancer. Front. Biosci. 12, 4254-4266.

O'Connor, D. S., Grossman, D., Plescia, J., Li, F., Zhang, H., Villa, A., Tognin, S., Marchisio, P. C., and Altieri, D. C. (2000). Regulation of apoptosis at cell division by $\mathrm{p} 34 \mathrm{cdc} 2$ phosphorylation of survivin. Proc. Natl. Acad. Sci. U.S.A. 97, 13103-13107.

Oesterling, J. E., Jacobsen, S. J., Klee, G. G., Pettersson, K., Piironen, T., Abrahamsson, P. A., Stenman, U. H., Dowell, B., Lovgren, T., and Lilja, H. (1995). Free, complexed and total serum prostate specific antigen: the establishment of appropriate reference ranges for their concentrations and ratios. $J$. Urol. 154, 1090-1095.

Ogata, T., Teshima, T., Kagawa, K., Hishikawa, Y., Takahashi, Y., Kawaguchi, A., Suzumoto, Y., Nojima, K., Furusawa, Y., and Matsuura, N. (2005). Particle irradiation suppresses metastatic potential of cancer cells. Cancer Res. 65, 113-120.

Oktay, M.H., Oktay, K., D. Hamele-Bena, Buyuk, A., and Koss, L. G. (2003). Focal adhesion kinase as a marker of malignant phenotype in breast and cervical carcinomas. Hum. Pathol. 34 240-245.

Onoda, J. M., Kantak, S. S., Piechocki, M. P., Awad, W., Chea, R., Liu, B., and Honn, K. V. (1994). Inhibition of radiation-enhanced expression of integrin and metastatic potential in B16 melanoma cells by a lipoxygenase inhibitor. Radiat. Res. 140, 410-418.

Pang, S. T., Weng, W. H., Flores-Morales, A., Johansson, B., Pourian, M. R., Nilsson, P., Pousette, A., Larsson, C., and Norstedt, G. (2006). Cytogenetic and expression profiles associated with transformation to androgen-resistant prostate cancer. Prostate 66, 157-172.

Park, C. C., Zhang, H. J., Yao, E. S., Park, C. J., and Bissell, M. J. (2008). $\beta 1$ integrin inhibition dramatically enhances radiotherapy efficacy in human breast cancer xenografts. Cancer Res. 68 , 4398-4405.

Parker, C. C., and Dearnaley, D. P. (2003), Radical radiotherapy for prostate cancer. Cancer Treat. Rev. 29, 161-169.

Patra, S. K., Patra, A., Zhao, H., and Dahiya, R. (2002). DNA methyltransferase and demethylase in human prostate cancer. Mol. Carcinog. 33, 163-171.

Perry, A. S., Foley, R., Woodson, K., and Lawler, M. (2006). The emerging roles of DNA methylation in the clinical management of prostate cancer. Endocr. Relat. Cancer 13, 357-377.

Pilepich, M. V., Winter, K., John, M. J., Mesic, J. B., Sause, W., Rubin, P., Lawton, C., Machtay, M., and Grignon, D. (2001). Phase III radiation therapy oncology group (RTOG) trial 86-10 of androgen deprivation adjuvant to definitive radiotherapy in locally advanced carcinoma of the prostate. Int. J. Radiat. Oncol. Biol. Phys. 50, 1243-1252.

Pilepich, M. V., Winter, K., Lawton, C. A., Krisch, R.E., Wolkov, H. B., Movsas, B., Hug, E. B., Asbell, S. O., and Grignon, D. (2005). Androgen suppression adjuvant to definitive radiotherapy in prostate carcinoma-long-term results of phase III RTOG 85-31. Int. J. Radiat. Oncol. Biol. Phys. 61, 1285-1290.

Pisansky, T. M. (2006). External-beam radiotherapy for localized prostate cancer. N. Engl.J. Med.355, 1583-1591.

Pisansky, T. M., Kahn, M. J., Rasp, G. M., Cha, S. S., Haddock, M. G., and Bostwick, D. G. (1997). A multiple prognostic index predictive of disease outcome after irradiation for clinically localized prostate carcinoma. Cancer 79, 337-344.

Pollack,A., Salem, N.,Ashoori, F., Hachem, P., Sangha, M., von Eschenbach, A. C., and Meistrich, M. L. (2001). Lack of prostate cancer radiosensitization by androgen deprivation. Int. J. Radiat. Oncol. Biol. Phys. 51, 1002-1007.

Pollack, A., Zagars, G. K., and Kopplin, S. (1995). Radiotherapy and androgen ablation for clinically localized highrisk prostate cancer. Int. J. Radiat. Oncol. Biol. Phys. 32, 13-20.

Pollack, A., Zagars, G. K., and Rosen, I. I. (1999). Prostate cancer treatment with radiotherapy: maturing methods that minimize morbidity. Semin. Oncol. 26, 150-161.

Pollack, A., Zagars, G. K., Starkschall, G., Antolak, J. A., Lee, J. J., Huang, E., von Eschenbach, A. C., Kuban, D. A., and Rosen, I. (2002). Prostate cancer radiation dose response: results of the $\mathrm{M}$. D. Anderson phase III randomized trial. Int. J. Radiat. Oncol. Biol. Phys. 53, 1097-1105.

Pratap, J., Lian, J. B., and Stein, G. S. (2011). Metastatic bone disease: role of transcription factors and future targets. Bone 48, 30-36.

Pratap, J., Wixted, J. J., Gaur, T., Zaidi, S. K., Dobson, J., Veeraraj, K. D., Hussain, S., van Wijnen, A. J., Stein, J. L., Stein, G. S., and Lian, J. B. (2008). Runx2 transcriptional activation of Indian hedgehog and a downstream bone 
metastatic pathway in breast cancer cells. Cancer Res. 68, 7795-7802.

Raffoul, J. J., Banerjee, S., Che, M., Knoll, Z. E., Doerge, D. R., Abrams, J., Kucuk, O., Sarkar, F. H., and Hillman, G. G. (2007). Soy isoflavones enhance radiotherapy in a metastatic prostate cancer model. Int. J. Cancer 120, 2491-2498.

Roach, M. III, Bae, K., Speight, J., Wolkov, H. B., Rubin, P., Lee, R. J., Lawton, C., Valicenti, R., Grignon, D., and Pilepich, M.V.(2008). Short-term neoadjuvant androgen deprivation therapy and external-beam radiotherapy for locally advanced prostate cancer: long-term results of RTOG 8610. J. Clin. Oncol. 26, 585-591.

Roach, M. III. (1999). Current status of androgen suppression and radiotherapy for patients with prostate cancer. J. Steroid Biochem. Mol. Biol. 69, 239-245.

Roudier, M. P., Corey, E., True, L. D., Hiagno, C. S., Ott, S. M., and Vessell, R. L. (2004). Histological, immunophenotypic and histomorphometric characterization of prostate cancer bone metastases. Cancer Treat. Res. 118, 311-339.

Roy, K., Wang, L., Makrigiorgos, G. M., and Price, B. D. (2006). Methylation of the ATM promoter in glioma cells alters ionizing radiation sensitivity. Biochem. Biophys. Res. Commun. 344, 821-826.

Rucci, N., and Teti, A. (2010). Osteomimicry: how tumor cells try to deceive the bone. Front. Biosci. (Schol. Ed.) 2, 907-915.

Saini, S., Majid, S., Yamamura, S., Tabatabai, Z. L., Suh, S. O., Shahryari, V., Chen, Y., Deng, G., Tanaka, Y., and Dahiya, R. (2010). Regulatory role of miR-203 in prostate cancer progression and metastasis. Clin. Cancer Res. PMID: 21159887. [Epub ahead of print].

Sainz, R. M., Reiter, R. J., Tan, D. X., Roldan, F., Natarajan, M., Quiros, I., Hevia, D., Rodriguez, C., and Mayo, J. C. (2008). Critical role of glutathione in melatonin enhancement of tumor necrosis factor and ionizing radiationinduced apoptosis in prostate cancer cells in vitro. J. Pineal Res. 45, 258-270.

Sandler, H. M. (2004). Optimizing hormone therapy in localized prostate cancer: focus on external beam radiotherapy. J. Urol. 172, S38-S41; discussion S41.

Schellhammer, P. F., Sharifi, R., Block, N. L., Soloway, M. S., Venner, P. M., Patterson, A. L., Sarosdy, M. F., Vogelzang, N. J., Schellenger, J. J., and Kolvenbag, G. J. (1997a). Clinical benefits of bicalutamide compared with flutamide in com- bined androgen blockade for patients with advanced prostatic carcinoma: final report of a double-blind, randomized, multicenter trial. Casodex Combination Study Group. Urology 50, 330-336.

Schellhammer, P. F., Venner, P., Haas, G. P., Small, E. J., Nieh, P. T., Seabaugh, D. R., Patterson, A. L., Klein, E., Wajsman, Z., Furr, B., Chen, Y., and Kolvenbag, G. J. (1997b). Prostate specific antigen decreases after withdrawal of antiandrogen therapy with bicalutamide or flutamide in patients receiving combined androgen blockade. J. Urol. 157, 1731-1735.

Scherr, D. S., Vaughan, E. D. Jr., Wei, J., Chung, M., Felsen, D., Allbright, R., and Knudsen, B. S. (1999). BCL-2 and p53 expression in clinically localized prostate cancer predicts response to external beam radiotherapy. J. Urol. 162, 12-16; discussion 16-17.

See, W. A., and Tyrrell, C. J. (2006). The addition of bicalutamide $150 \mathrm{mg}$ to radiotherapy significantly improves overall survival in men with locally advanced prostate cancer. J. Cancer Res. Clin. Oncol. 132(Suppl. 1), S7-S16.

Shahinian, V. B., Kuo, Y. F., Freeman, J. L., and Goodwin, J. S. (2005). Risk of fracture after androgen deprivation for prostate cancer. N. Engl. J. Med. 352, 154-164.

Shiloh, Y. (2003). ATM and related protein kinases: safeguarding genome integrity. Nat. Rev. Cancer 3, 155-168.

Simon, E. L., Goel, H.L., Teider, N., Wang, T., Languino, L. R., and Fitzgerald, T. J. (2005). High dose fractionated ionizing radiation inhibits prostate cancer cell adhesion and $\beta 1$ integrin expression. Prostate 64, 83-91.

Smith, R. A., and Giorgio, T. D. (2004). Quantitation and kinetics of CD51 surface receptor expression: implications for targeted delivery. Ann. Biomed. Eng. 32, 635-644.

Sreevalsan, S., Jutooru, I., Chadalapaka, G., Walker, M., and Safe, S. (2009). 1,1-Bis(3'-indolyl)-1-(pbromophenyl)methane and related compounds repress survivin and decrease gamma-radiation-induced survivin in colon and pancreatic cancer cells. Int. J. Oncol. 35, 1191-1199.

Steel, G. G. (2001). The case against apoptosis. Acta Oncol 40, 968-975.

Szostak, M. J., and Kyprianou, N. (2000). Radiation-induced apoptosis: predictive and therapeutic significance in radiotherapy of prostate cancer (review). Oncol. Rep. 7, 699-706.

Tu, S. M., Lin, S. H., Podoloff, D. A., and Logothetis, C. J. (2010). Multimodality therapy: bone-targeted radioisotope therapy of prostate cancer. Clin. Adv. Hematol. Oncol. 8, 341-351.

Udayakumar, T.S., Stoyanova, R., Hachem, P., Ahmed, M. M., and Pollack, A. (2011). Adenovirus E2F1 overexpression sensitizes LNCaP and PC3 prostate tumor cells to radiation in vivo. Int. J. Radiat. Oncol. Biol. Phys. 79, 549-558.

Valicenti, R. K., Bae, K., Michalski, J., Sandler, H., Shipley, W., Lin, A., and Cox, J. (2011). Does hormone therapy reduce disease recurrence in prostate cancer patients receiving dose-escalated radiation therapy? An analysis of Radiation Therapy Oncology Group 94-06. Int. J. Radiat. Oncol. Biol. Phys. 79, 1323-1329.

van der Deen, M., Akech, J., Wang, T., FitzGerald, T. J., Altieri, D. C., Languino, L. R., Lian, J. B., van Wijnen, A. J., Stein, J. L., and Stein, G. S. (2010). The cancer-related Runx2 protein enhances cell growth and responses to androgen and TGF $\beta$ in prostate cancer cells. J. Cell. Biochem. 109, 828-837.

Veldscholte, J., Voorhorst-Ogink, M. M., Bolt-de Vries, J., van Rooij, H. C., Trapman, J., and Mulder, E. (1990). Unusual specificity of the androgen receptor in the human prostate tumor cell line LNCaP: high affinity for progestagenic and estrogenic steroids. Biochim. Biophys. Acta 1052, 187-194.

Wang, G., Reed, E., and Li, Q. Q. (2004). Apoptosis in prostate cancer: progressive and therapeutic implications (review). Int. J. Mol. Med. 14, 23-34.

Wang, T., Alavian, M. R., Goel, H. L., Languino, L. R., and Fitzgerald, T. J. (2008). Bicalutamide inhibits androgen-mediated adhesion of prostate cancer cells exposed to ionizing radiation. Prostate 68, 1734-1742.

Wang, T., Huang, J., Alavian, M. R., Goel, H. L., Languino, L. R., and FitzGerald, T. J. (2007). $\alpha v \beta 3$ integrin promotes resistance of prostate cancer cells to ionizing radiation. Int. J. Radiat. Oncol. Biol. Phys. 69, S611.

Weber, M., and Schubeler, D. (2007). Genomic patterns of DNA methylation: targets and function of an epigenetic mark. Curr. Opin. Cell Biol. 19,273-280.

Weidman, J. R., Dolinoy, D. C., Murphy, S. K., and Jirtle, R. L. (2007). Cancer susceptibility: epigenetic manifestation of environmental exposures. Cancer J. 13, 9-16.

Widmark, A., Klepp, O., Solberg, A., Damber, J. E., Angelsen, A., Fransson, P., Lund, J. A., Tasdemir, I., Hoyer, M., Wiklund, F., and Fossa, S. D. (2009). Endocrine treatment, with or without radiotherapy, in locally advanced prostate cancer (SPCG-7/SFUO-3): an open randomised phase III trial. Lancet 373, 301-308.

Wild-Bode, C., Weller, M., Rimner, A., Dichgans, J., and Wick, W. (2001). Sublethal irradiation promotes migration and invasiveness of glioma cells: implications for radiotherapy of human glioblastoma. Cancer Res. 61, 2744-2750.

Wu, C. T., Chen, W. C., Liao, S. K., Hsu, C. L., Lee, K. D., and Chen, M. F. (2007). The radiation response of hormoneresistant prostate cancer induced by long-term hormone therapy. Endocr. Relat. Cancer 14, 633-643.

Yang, J., Fizazi, K., Peleg, S., Sikes, C. R., Raymond, A. K., Jamal, N., Hu, M., Olive, M., Martinez, L. A., Wood, C. G., Logothetis, C. J., Karsenty, G., and Navone, N.M. (2001). Prostate cancer cells induce osteoblast differentiation through a Cbfal-dependent pathway. Cancer Res. 61, 5652-5659.

Yegnasubramanian, S., Haffner, M. C., Zhang, Y., Gurel, B., Cornish, T. C., Wu, Z., Irizarry, R. A., Morgan, J., Hicks, J., DeWeese, T. L., Isaacs, W. B., Bova G. S., De Marzo, A. M., and Nelson, W. G. (2008). DNA hypomethylation arises later in prostate cancer progression than CpG island hypermethylation and contributes to metastatic tumor heterogeneity. Cancer Res. 68, 8954-8967.

Yegnasubramanian, S., Kowalski, J., Gonzalgo, M. L., Zahurak, M., Piantadosi, S., Walsh, P. C., Bova, G. S., De Marzo, A. M., Isaacs, W. B., and Nelson, W. G. (2004). Hypermethylation of $\mathrm{CpG}$ islands in primary and metastatic human prostate cancer. Cancer Res. 64, 1975-1986.

Yu, Y. P., Landsittel, D., Jing, L., Nelson, J., Ren, B., Liu, L., McDonald, C., Thomas, R., Dhir, R., Finkelstein, S., Michalopoulos, G., Becich, M., and Luo, J. H. (2004). Gene expression alterations in prostate cancer predicting tumor aggression and preceding development of malignancy. J. Clin. Oncol. 22, 2790-2799.

Zagars, G. K., Pollack, A., and von Eschenbach, A. C. (2001). Addition of radiation therapy to androgen ablation improves outcome for subclinically node-positive prostate cancer. Urology 58, 233-239.

Zaidi, S. K., Young, D. W., Javed, A., Pratap, J., Montecino, M., van Wijnen, A., Lian, J. B., Stein, J. L., and Stein, G. S. (2007). Nuclear microenvironments in biological control and cancer. Nat. Rev. Cancer 7, 454-463.

Zhang, M., Coen, J. J., Suzuki, Y., Siedow, M. R., Niemierko, A., Khor, L. Y., Pollack, A., Zhang, Y., Zietman, A. L., Shipley, W. U., and Chakravarti, 
A. (2010a). Survivin is a potential mediator of prostate cancer metastasis. Int. J. Radiat. Oncol. Biol. Phys. 78, 1095-1103.

Zhang, P., Singh, A., Yegnasubramanian, S., Esopi, D., Kombairaju, P., Bodas, M., Wu, H., Bova, S. G., and Biswal, S. (2010b). Loss of Kelch-like ECHassociated protein 1 function in prostate cancer cells causes chemoresistance and radioresistance and promotes tumor growth. Mol. Cancer Ther. 9, 336-346.

Zhang, M., Ho, A., Hammond, E. H., Suzuki, Y., Bermudez, R. S., Lee, R. J., Pilepich, M., Shipley, W. U., Sandler, H., Khor, L. Y., Pollack, A., and Chakravarti, A. (2009). Prognostic value of survivin in locally advanced prostate cancer: study based on RTOG 8610. Int. J. Radiat. Oncol. Biol. Phys. 73, 1033-1042.

Zhang, M., Latham, D. E., Delaney, M. A., and Chakravarti, A. (2005). Survivin mediates resistance to antiandrogen therapy in prostate cancer. Oncogene 24, 2474-2482.

Zhang, P., Castedo, M., Tao, Y., Violot, D., Metivier, D., Deutsch, E., Kroemer, G., and Bourhis, J. (2006). Caspase independence of radio-induced cell death. Oncogene 25, 7758-7770.

Zhou, H., Miki, R., Eeva, M., Fike, F. M., Seligson, D., Yang, L., Yoshimura, A., Teitell, M. A., Jamieson, C. A., and Cacalano, N. A. (2007). Reciprocal regulation of SOCS 1 and SOCS3 enhances resistance to ionizing radiation in glioblastoma multiforme. Clin. Cancer Res. 13, 2344-2353.

Zietman, A. L., Nakfoor, B. M., Prince, E. A., and Gerweck, L. E. (1997). The effect of androgen deprivation and radiation therapy on an androgensensitive murine tumor: an in vitro and in vivo study. Cancer J. Sci. Am. 3, 31-36.

Conflict of Interest Statement: The authors declare that the research was conducted in the absence of any commercial or financial relationships that could be construed as a potential conflict of interest.
Received: 17 March 2011; accepted: 27 June 2011; published online: 13 July 2011.

Citation: Wang T, Languino LR, Lian J, Stein G, Blute M and FitzGerald TJ (2011)

Molecular targets for radiation oncology in prostate cancer. Front. Oncol. 1:17. doi: 10.3389/fonc.2011.00017

This article was submitted to Frontiers in Radiation Oncology, a specialty of Frontiers in Oncology.

Copyright (c) 2011 Wang, Languino, Lian, Stein, Blute and FitzGerald. This is an openaccess article subject to a non-exclusive license between the authors and Frontiers Media $S A$, which permits use, distribution and reproduction in other forums, provided the original authors and source are credited and other Frontiers conditions are complied with. 